\title{
Background to 'Sulphate Sunrise' - investigating New Caledonia
}

\section{ABSTRACT}

Reporting on Vale SA, the Brazilian-based world's second-largest nickel producer which aims to start production soon at its US $\$ 4.5$ billion Goro refinery project in New Caledonia, represents a good example of the need to dedicate time building contacts on the ground and speaking to a variety of sources. This article examines a Global Mail investigation into an environmental issue that is complex from a scientific and technological point of view, but is further complicated by the multiple social, ethical, and spiritual perspectives linked to it. The mine is deeply embedded in a specific local political, economical and social framework-that of decolonisation and questions over legitimacy of power (Horowitz 2009, p. 249; van Vuuren 2008, p. 74). In terms of sources, a French environmentalist will have a radically different perspective to the environment to that of an indigenous Kanak, for whom land is first and foremost the source of identity and dignity. Views within the Kanak community also diverge.

Keywords: decolonisation, environmental journalism, human rights, indigenous, investigative journalism, mining

\section{NICOLE GOOCH}

Australian Centre for Independent Journalism

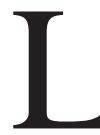

IVING and working in New Caledonia in the second half of the 2000s, one could not help be aware of the new \$US4.5 billion Brazilian nickel refinery taking shape in the south of the country. With plans to export 60,000 tonnes of refined nickel every year, its owner, Vale, is set to soon become the world's largest producer of nickel.

However, the mine has created much resentment among the local indigenous communities of the south of New Caledonia, and among environmentalists. Vale New Caledonia will be using new technology to refine the nickel, called high pressure acid leaching, which if not carefully controlled, poses a great risk to the surrounding environment.

148 PACIFIC JOURNALISM REVIEW 18 (1) 2012 
Like most projects in the Pacific, Australians have been involved. For like busy worker ants, whether they are liked or not, Australians are found everywhere in the Pacific - morphed into aid consultants, RAMSI officials, business owners, missionaries and contractors. Australian companies are significant shareholders in the \$US15 billion PNG LNG Project. The New Caledonian project is no exception with Australians playing key roles in the construction of the new nickel refinery.

However, there has been little news about the project in Australia. This relative invisibility of the project in Australian media is probably not surprising as it reflects broader patterns. Indeed, the Pacific region as a whole, despite its geographical proximity to Australia, receives only scarce coverage in mainstream Australian news media. What coverage there is tends to appear when there is a perceived crisis including the occasional political coup or a dramatic natural disaster (Mason 2001, p.57; Perrottet \& Robie, 2011).

There has not been a lot of research into this lack of coverage. In 2000, Nash \& Bacon conducted an extensive study of international aid and development news during the six months leading up to March 2000 across Australian mainstream print, radio and television media, and found that only 5.4 percent of that coverage concerned the Pacific (Nash \& Bacon 2002, p. 71). This is despite the fact that at the time, the Pacific attracted nearly 30 percent of Australia's annual aid budget (Nash \& Bacon, 2002, p.73).

In general we can say that regular coverage which Australian audiences receive on aid and development issues relates to very few countries. In the six months analysed, Australians received little information about aid and development issues in most of the poorer countries of the world. Once the Mozambique floods stories were discounted, there were very few stories on any country in Africa. There were hardly any stories on South American or Central American countries. Most Pacific nations receive little or no coverage. (Nash \& Bacon, 2002, p.76).

Coverage of Vale New Caledonia's nickel refinery confirmed those statistics - as construction of the plant progressed, despite conflicts with the local population and environmental degradation problems, the author was surprised by how little news there was about it in the Australian media. Looking for answers as to why this was the case, while simultaneously starting her own published investigation (Gooch, 2012), the author supplemented Nash \& Bacon's findings with four interviews with Australian journalists who had 
worked in the Pacific. All interviewees expressed concern about how the Pacific is covered by media, and the impact this has on the Australian public's perception of the region.

Pacific veteran journalist and ABC correspondent, Sean Dorney told the author he was gravely concerned about the lack of coverage: 'For all the money that Australia spends on the Pacific, too few journalists are actually playing a watch dog role' (S. Dorney, personal communication, 3 November 2009). Solomon Islands-based freelance journalist Lisa Williams-Lahari agreed with Dorney, arguing that coverage was not only insufficient but also superficial. 'When there is news coverage of the Pacific, it is usually just a mere chicken scratch across the surface of issues,' she said. (personal communication, 3 November 2009). Likewise, media coverage rarely probes beyond the 'top layer', according to The Australian's former South Pacific correspondent and Gold Walkley winner Mary-Louise O'Callaghan, who now lives in Solomon Islands and is media adviser to RAMSI (personal communication, 3 November 2009).

However, the reasons behind the media's simplification and distortion of complex situations (Nash \& Bacon, 2002, p. 53), are nearly as complex as the situations themselves. Gradually, the number of correspondents has decreased as funding dwindled and Australia's attention shifted to Asia from the 1980s. As editorial resources to cover even local environmental and development issues have declined, few newsrooms have the time and capacity available to dedicate to covering the Pacific on a regular basis and in any depth, let alone a complicated environmental issue in a French-speaking region that is mainly known in Australia as a tourist destination, an image to which the media itself has contributed. Even the two public broadcasters' international television programmes ABC's Foreign Correspondent and SBS's Dateline, have been more constrained in what they can cover, which means that the chance of the very serious social and environmental impacts of international resources projects in the Pacific being subject to regional media scrutiny is slight indeed.

A further hurdle for Pacific news is that, in addition to time and costs, editorial policy and assumptions about the level of interest of local Australian audiences are all factored into the decisions as to which stories becomes news, regardless of their significance (Nash \& Bacon, 2002, p. 8). Lack of coverage feeds confirms and reinforces lack of coverage.

With the exception of the ABC's Radio Australia, when regional news does sometimes make it into mainstream media, Pacific news is usually sourced 
from wire services, or through 'parachute journalists' who are flown in to cover times of crisis (Mason, 2001; Williams-Lahari, 2009).

Nash \& Bacon reported that The Sydney Morning Herald had its stringer budget cut by 60 percent in 2001. They concluded: 'If a crisis does blow up in one of these places, the paper will be less likely to have a regular contributor with contacts and information about the area. The paper is dependent on wire services to cover whole areas of the globe' (Nash \& Bacon, 2002, p. 185). As media budgets have become further squeezed freelance budgets, rates and resources have further reduced. Even if strong Pacific reporters are available, they are rarely commissioned by Australian publications.

This has repercussions not only on which stories are told, but also on how they are told. Nash \& Bacon found that 'parachute journalism' is made possible by more sophisticated transport and communication technologies, but is also responsible for a breed of generalist reporters trained in 'crisis, not countries'. 'Such reporters bring back increasingly generic images and anecdotal stories that capture one salient aspect of a place rather than a more complex understanding' (Nash \& Bacon, 2002, p. 53).

For a story such as the one of the Vale New Caledonia refinery, set amid a complex web of politics as well as social and environmental issues, none of which can really be separated from one another, parachute journalism is unlikely to do it justice.

O'Callaghan argued similarly that news of the Pacific often ends up looking more like a 'once over police report' (M.L. O'Callaghan, personal communication, 3 November 2009), which can be misleading. 'It is not necessarily that the reporting is factually inaccurate, but just providing a top layer can provide inaccurate perceptions of the news for the readers or audience,' argued O'Callaghan, who wrote the 1999 book Enemies within: Papua New Guinea, Australia and the Sandline Crisis: the inside story, after realising that perceptions in Australia of the historical events that took place in 1997 in PNG were 'slightly off the real story'.

O'Callaghan confirmed that since she had begun working as a journalist in the Pacific the lack of focus on the region and the resources allocated to it had got even worse. 'The nature of the beast has changed.... These days reporters are under huge pressures to file news stories and take videos, so there is very little time left for research and talking to sources and looking at different angles' (personal communication, 3 November 2009). 
O'Callaghan's experience further reinforces Nash and Bacon's study which showed that in '42.6 percent of stories only one source was quoted', thus 'limiting opportunities for a plurality of perspectives to be expressed in mainstream news' (2002, p. 92). These authors also found that 'official sources - politicians, officers of organisations and government officialsdominate media discourse about aid and development issues, far outweighing voices of other individuals, even when they are 'experts' (doctors, lawyers etc)' (2002, p. 92). Constrained by a lack of time, journalists are reduced to relying on official sources to provide the definition of stories, which simplifies the issues and limits the likelihood of scrutiny or critical reporting, otherwise achieved through the use of non-official sources, or counter-definers (Bacon, 2005; Hall et al., 1978).

However, as elsewhere, there are many sources in the Pacific, such as local NGOs and grassroots organisations, which could provide firsthand or 'authoritative' accounts (Ericson, 1989), or provide alternative versions to those provided by official sources, but reporters need time as well as local knowledge to access them. Most of these sources lack the cultural capital and resources to actively assert their 'legitimacy' and are therefore less likely to successfully compete for access to busy journalists against international bodies with greater economic and cultural capital such as the UN agencies or global NGOs like Oxfam or Greenpeace (Schlesinger, 1990).

In addition, 'The smallness of a society [in the Pacific] is often deceptive, and what happens does not necessarily happen through the western public sphere,' argued another Australian journalist interviewed for this research, who preferred to remain anonymous. 'Because of the smallness of the communities, a lot of things that happen are actually unspoken, but understood, because of family connections, culture and history' (personal communication, 4 November 2009). Unless a journalist can afford the time to listen and acknowledge the various dynamics of these societies, then her short hand and simple binary distinction of events can lead to misleading reporting, or misrepresentation, even if the use of official sources gives the news report credibility (Nash, 2009).

By relying solely on official sources, journalists risk framing their reporting of the Pacific within two categories. The anonymous journalist called this 'the paradise lost dichotomy'. 
The Paradise stories that get a run in the Australian media are largely tourism stories, framed through images of the Pacific as a tourist paradise with smiling natives and swaying palms. Paradise Lost is the tsunamis, coups, corruption, rape and murder in PNG, Bainimarama, RAMSI. In between those two, there is very little. The daily life of people - agriculture, religion, school fees-all the things we battle with in Australia, are missing.

Consequently, the Australian public's perception of the Pacific becomes distorted through this public mediation (McCallum, 2007; Romano, 2007), to the extent where it leads to confusion at the best of times, and at worst can bring about a negative and patronising, if not racist, perception of the Pacific.

However, in these examples of media framing of the Pacific, journalists are merely bringing into the public sphere representations of the region that fit editorial policies and 'news stagings' of wars, disasters and climate change as global crises (Cottle, 2009), whilst still appearing credible to the public.

Furthermore, it becomes a 'chicken and egg situation', argued O'Callaghan. 'With a complete absence of TV footage of the Pacific, nobody knows about it, except when there is a crisis and viewers are suddenly bombarded with images of tsunamis and coups. Yet, if there is not more regular news coverage, then there can't be any demand for it either' (personal communication, 3 November 2009.)

Lack of ongoing and in-depth coverage also makes it harder for the audience or readers to understand what is happening in the midst of this sudden onslaught of images and news. In addition, they are provided with too little information to understand the connection between the events reported and their own lives. Consequently, the audience and readers lose interest quickly (Glasgow Media Group, p. 4). It becomes a vicious circle.

Investigating Vale New Caledonia's nickel refinery is therefore a good example of the need to dedicate time to building contacts on the ground and speaking to a variety of sources who could elucidate very specific political, economical and social framework-that of decolonisation and questions over legitimacy of power (Horowitz 2009, 249; van Vuuren 2008, p. 74). It is also an example of an investigation into an environmental issue, which as in environmental reporting generally raised difficult scientific issues of levels of risk (Anderson, 1997, p. 168).

So in this context, what placed the author in the situation of being able 
to carry out this investigation? The author speaks fluent English and French, having grown up on the island, and she was back living in New Caledonia between 2005 and 2009, at the height of the tensions surrounding the mine. All these factors put her at a considerable advantage in terms of having access to a variety of sources and an initial understanding of some of the complexities of the issues surrounding the mine - advantages that are not within easy reach for most mainstream journalists these days.

In terms of sources, it is useful for instance to be aware that a French environmentalist, no matter how long he or she has lived in New Caledonia, would have quite a radically different perspective to the environment from that of an indigenous Kanak, for whom land is first and foremost the source of identity and dignity (Horowitz, 2002, p. 35).

Views within the Kanak community diverge further as well. As anthropologist Leah Horowitz found (Horowitz, 2002): 'Local communities are not the homogeneous entities unanimously opposed to industrial development, that academic and popular literature often portray them to be.'

It is however difficult to obtain access to the villagers who live on the island that sits across from the refinery. The author was able to gain the trust of the people in the village because she travelled there with a local Kanak filmmaker, who she contacted through three other sources. She stayed on the island, in the Ouara tribe, for a couple of days. She is not sure what sort of welcome she would have received if she had arrived uninvited, particularly as a young, white, Australian female. Nevertheless, the fact that her aim was to produce a story for the Australian media helped me in my efforts to speak to crucial local sources as although the Australian media had demonstrated little interest in their situation, She found the villagers were keen to share their story and concerns to communities beyond the borders of New Caledonia.

Neither of her two key sources on Ile Ouen have regular access to the internet, and only one of them has a mobile phone, which works as long as the network works, and it does nor receive international calls. It is easier to speak with them by calling the public phone that stands in the middle of the village, in the hope that someone walks past at that exact moment. This takes time and perseverance, therefore making it difficult to give an ongoing public voice in the Australian media to the people on the island without actually going there.

The author was also fortunate to have access to the English-speaking community working at the mine. Local journalists were not necessarily aware 
for instance of some of the refinery's design faults and risks, because these issues were mostly only raised by the Australian or Canadian engineers when discussing it among themselves. Being for the most part fly-in/fly out workers, they were more open to when asked about these issues as they were taking fewer risks than local workers who had move to lose.

As is necessary for any investigative journalist, the author tracked down and attempted to speak to many sources, but most would not talk 'on the record'. While she could not quote or expose these sources in any way, speaking with them was an essential part of understanding the complex situation.

As Hall, Schlesinger and other have argued, the media often over access powerful business or government sources (Hall, 1978; Schlesinger, 1990). One of the key goals driving my reporting practices was a desire to not repeat that mistake. However, it was nevertheless important to gain their perspective both to be able to put concerns and allegations to them on behalf of the public and from an ethical 'fairness' point of view. However, the author's repeated requests for interviews with the Vale New Caledonia's executive management team in Noumea were met by a solid front of communications officers, whom she could not get past. Eventually, one communications officer agreed to respond to questions by email, but not all questions were answered. This is regrettable as Vale's representation of events is an important element in understanding the issues with which the local population and environmentalists are confronted. The fact that they will now answer these questions has at least been recorded and becomes part of the story. This experience is not unusual for an investigative journalist but it is also possible that if I had been from a major international organisation, she would have more success in negotiating with this powerful source.

The author was privileged to have the opportunity to work on this story over quite a long period. In the process, she gained a new appreciation of how the structural issues confronting Australian journalism, difficulties in communication and lack of local knowledge and contacts combine to make it difficult for New Caledonian communities and other communities in their Pacific to communicate with the Australian public about their interests and concerns. She also realised that further tracking of events is needed and that ongoing scrutiny of this and other major developments in the Pacific by the international as well as local Pacific media is crucial to give communities who are directly impacted a voice. 
In conclusion, Pacific issues, both positive and negative, need, in as much as possible, to be covered as 'ongoing, newsworthy issues', partly because Australia is heavily involved in the region, with Australian tax payers' money. Journalists need to find ways to engage with the communities rather than talkup their problems and rely only on elite sources (McCullum, 2007, p. 12). Failing that, the danger is that, for the Australian and international publics not directly engaged on an ongoing basis with the Pacific, superficial mediated representations become their only perspectives, and 'map the contours of public debate' (McCallum 2007, p. 3) in ways that does not contribute to community understanding of development issues (2007, p. 12).

If the Australian public is not regularly exposed to the complexity of issues relating to the Pacific, and if in addition the few stories that are published only reflect perspectives of dominant forces in political and business fields (Nash, 2009), then the public can hardly be expected to be responsive to progressive policies promoting solutions to issues and conflicts arising from environmentally risky and socially disruptive developments. Lack of coverage also contributes to a lack of critical community engagement with the government's aid policy and its implementation in the Pacific, or indeed with the impact of Australian and other international companies' exploitation of non-renewable resources in conditions that would be unlikely to be approved in Australia.

\section{References}

Anderson, A. (1997). Media, culture and the environment. New York: Routledge.

Bacon, W. (2005). A case study in ethical failure: Twenty years of media coverage of Aboriginal deaths in custody, Pacific Journalism Review, 11(2), pp. 18-41.

Cottle, S. 2009. Global crisis in the news: Staging new wars, disasters, and climate change', International Journal of Communication, 3, pp. 494-516.

Ericson, R., Baranek, P. and Chan, J. (1989) Negotiating control. In Negotiating control: A study of news sources (pp. 377-398). Toronto: University of Toronto.

Gooch, N. (2012, April 27). Nickel and maligned, The Global Mail. Available at: www.theglobalmail.org/feature/nickel-and-maligned/214/

Glasgow Media Group. The mass production of ignorance: News content and audience understanding. Retrieved on 14 April 2012, from www.glasgowmediagroup. org/content/view/9/9/

Gooch, N. (2012, April 27). Nickel and maligned, The Global Mail. Available at: www.theglobalmail.org/feature/nickel-and-maligned/214/

Hall, S., Critcher, C., Jefferson, T., Carle, J. and Roberts, B. (1978). The social production of news. In Policing the crisis: Mugging, the state and law and order (pp. 53-77). London: Macmillan. 
Horowitz, L. (2009). Environmental violence and crises of legitimacy in New Caledonia, Political geography, 29, pp. 248-258.

Horowitz, L. (2002). Daily, immediate conflicts: an analysis of villagers' arguments about a multinational nickel mining project in New Caledonia', Oceania, 73(1), pp. 35-55.

Mason, A. (2001). Coups and conflict, Pacific Journalism Review, 7(1), pp. 57-64.

Mason, A. (2007). Elite sources, journalistic practice and the status quo, Pacific Journalism Review, 13(1), pp. 107-123.

McCallum, K. (2007). Indigenous violence as a 'mediated public crisis', ANZCA2007 Conference Proceedings.

Nash, C. and Bacon, W. (2002). News/worthy: How the Australian media cover humanitarian, aid and development issues, AusAID. Retrieved on 14 April 2012, from www.ausaid.gov.au/publications/pdf/newsworthy.pdf

Roberts, J., and Nash, C. (2009). Reporting controversy in health policy: a content and field analysis, Pacific Journalism Review, 15(2), pp. 35-53.

O'Callaghan, M.-L. (1999). Enemies within: Papua New Guinea, Australia, and the Sandline crisis: The inside story. Sydney: Doubleday Books.

Perrottet, A., and Robie, D. (2011). Papua a media black spot, New Matilda. Retrieved on 14 April 2012, from www.newmatilda.com/2011/10/24/papua-media-black-spot

Romano, A. (2007). The news media's representation of asylum seekers. In Lusher, D., Yearning to breathe free: Seeking asylum in Australia (pp. 183-198). Sydney: The Federation Press.

Schlesinger, P. (1990). Rethinking the sociology of journalism: Source strategies and the limits of media-centrism'. In Ferguson, M., Public communication: the news imperatives: Future directions for media research (pp. 61-83). London: Sage.

Van Vuuren, K. and Lester, L. (2008). Ecomedia: Of angelic images and environmental values, Media International Australia, 127, May 2008., pp. 71-81 Brisbane: University of Queensland.

Nicole Gooch is a freelance journalist from New Caledonia, who covers environmental, maritime and health issues. She previously worked in public health at the Secretariat of the Pacific Community (SPC). She wishes to thank Professor Wendy Bacon and Susie Eisenhuth for their guidance and support with this research, conducted as part of a Master in Journalism degree at the University of Technology, Sydney. An earlier version was presented at the 'Back to the Source' investigative journalism conference at UTS in September 2011. Gooch is an associate of the Australian Centre for Independent Journalism at UTS.

nicolesgooch@gmail.com 


\section{SULPHATE SUNRISE}

First published in The Global Mail as 'Nickel and Maligned'.

\section{By Nicole Gooch}

S New Caledonia's tropical sun elbowed its way through darkness
early one morning of October 2008, the tiny village of Goro was still
wrapped in sleepy silence, if not for the sound of the sea scrubbing its back on the black sand beach. It should have been an ordinary start to the day for the string of houses nestled at the extreme end of the island, under a heavy canopy of forest.

But instead, 65-year-old grandmother Maeva Dremon woke up to what she recalls as a 'shocking' view. La Trûû River, which flows past the back of her house on its way to the sea, had turned fluorescent green overnight. 'It was incredible, I had never seen anything like it,' says Dremon. Even her husband and his mates, on their way to work, stopped to clean their headlights and specs in disbelief.

For far from postcard shots of white sandy beaches and the temptations of French food, the South Pacific island territory of New Caledonia has a well-kept secret. It is neither exotic nor picturesque, and is at odds with the island's carefully-crafted sales pitch as a romantic tourist destination. Just a couple of hours' out of New Caledonia's capital the landscape changes dramatically. Leaving behind the French Riviera style ambience of Nouméa, the road heading south soon trails deep inland through eerie valleys of deep red soil and prehistoric scrub.

As it reaches the end of the Grand Terre island, layers of blue lagoon listed as UNESCO world heritage sites make a spectacular appearance from the crest of the hills.

But then, plunging deep inside the next valley, another spectacular phenomenon, this one man-made, suddenly emerges and a vast armada of shiny metal and fumes fills up the entire horizon in the blink of an eye.

The sprawling grey armoury of pipes and columns is a US\$4.5 billion nickel refinery belonging to Brazilian mining giant Vale, due to start full production next year. But it is off to a rocky start.

Ever since construction first begun 10 years ago, the refinery has struggled against waves of indigenous and environmental rights' protests. Hoping for a fresh start, Vale finally brokered a 'Sustainable Development Agreement' with New Caledonia's indigenous Kanak leaders in 2008. 


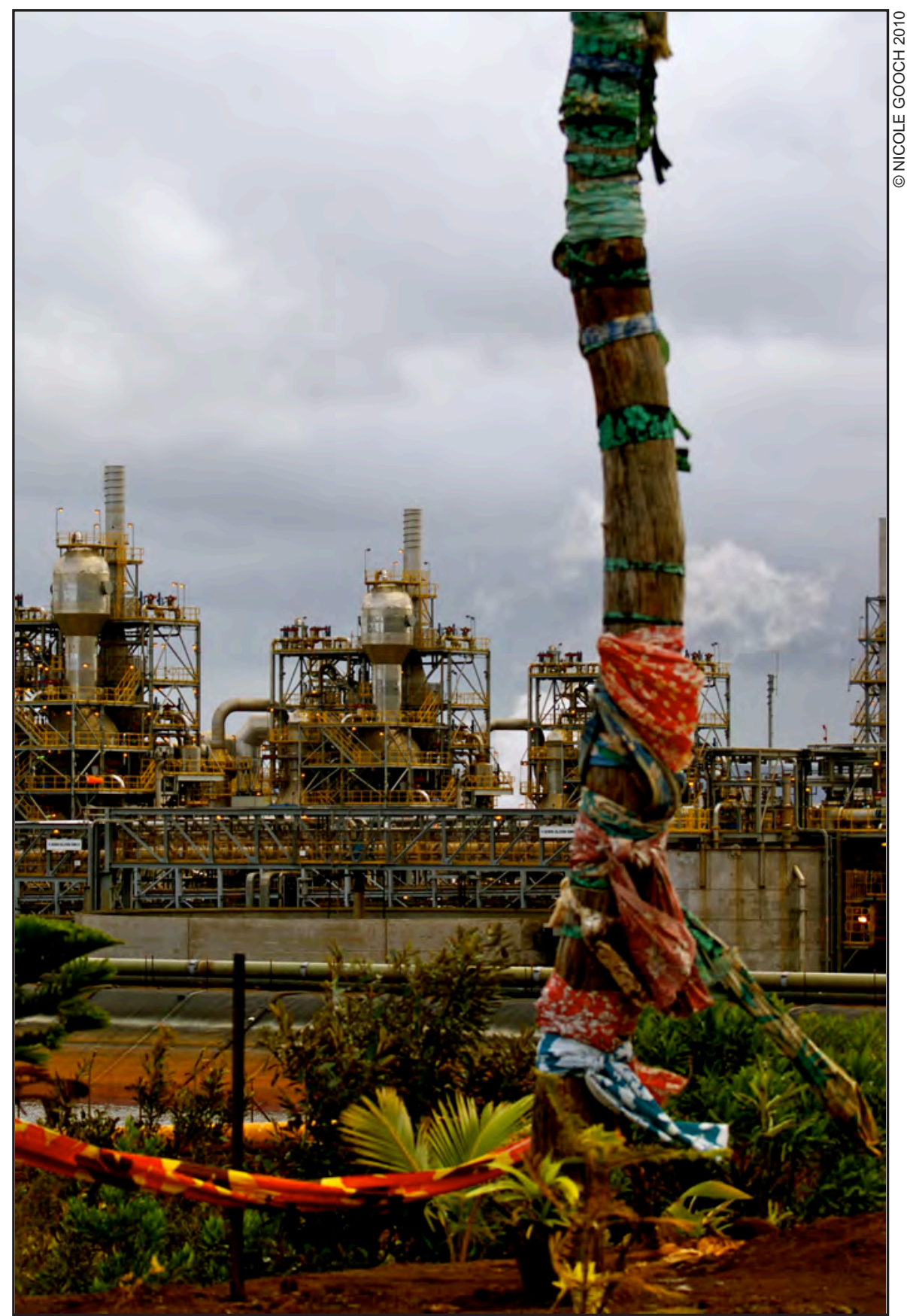

Figure 1: Bois Tabou outside the entrance to the Vale New Caledonia nickel refinery in Goro, New Caledonia. 
Vale New Caledonia now aims to become the world's largest nickel producer, with an anticipated annual output of 60000 tonnes of refined nickel and 4000 tonnes of cobalt, most of it destined for China. So far, however, the company has only sold about 3000 tonnes of semi-finished metal, to Clive Palmer's Queensland Nickel (QNI). And despite the signature of the agreement, questions over the refinery still abound.

Maeva Dremon now laughs as she recalls the green water episode-it turned out to be the fault of a 'non-toxic' chemical tracer added further up the river by technicians at the refinery, but she is nevertheless anxious about the future. Dremon says she is 'frightened' and sometimes wishes the agreement had not been signed, as it allowed the mine to go ahead.

'I'm glad my children have been able to find work at the mine,' says Dremon. 'But it is a difficult choice, because, on the other hand, I am worried about the future. We need to protect our environment, customs and traditions, and I am scared that these are getting lost in the process of modernisation.'

Mining is not new to New Caledonia. The French Overseas Country of 250,000 inhabitants, with a vote on independence due between 2014 and 2018 , owns 25 percent of the world's nickel resources, and is the green ore's third largest producer. But this mine is different.

On its Goro site, Vale is testing an unconventional nickel treatment method called high-pressure acid leaching, or hydrometallurgy technology, which should allow for the difficult extraction of low-grade nickel ore in the face of dwindling global stocks of high-grade ore. However, high pressure acid leaching has proven difficult to master elsewhere, including in Australia, and it has never been trialed on such a scale. In addition to the nickelprocessing plant, the project involved building an industrial port, a coal-fired power station, acid and limestone factories, a waste treatment plant, offices, accommodation for 3000 workers, a warehouse, tailings' storage and a 24-km waste outflow pipe into the lagoon. The Vale New Caledonia site is classified as a 'SEVOSO II' risk, the highest possible level of risk of an industrial accident by European Union standards-a classification system created after a chemical cloud from a factory in Sevoso, Italy, poisoned the town's population and killed more than 3000 domestic animals in 1976. As such, Vale has had to make arrangements with hospitals in Australia to treat possible burn victims.

Spread out over 22 ha, the project is therefore a massive chemical experiment, matched in scope only by the amount of angst, anger, and at times violence, it has caused in New Caledonia.

Environmental activists are still angry following an acid spill at the plant in 
April 2009, which flooded a river that flows into the UNESCO World Heritage bumper zone. Some 3000 fish were killed, four species of which are endemic to New Caledonia and two listed as endangered on the IUCN 'red list '.

Vale was due to face court over the pollution, but in August 2011 the police tribunal dismissed the case, citing the time lapse since the accident. Martine Cornailles, president of the environmental NGO Ensemble pour la Planète, says the NGO was appalled that Vale had escaped a judgment, 'because the police investigation left no doubt: from mistakes to guilty negligence, the accident was bound to happen'. A determined Ensemble pour la Planète finally won an appeal against Vale in April 2012. The mining company was fined $€ 3750$ (about $A \cup \$ 5000$ ), for the April 2009 acid leak into the river. But Cornailles says it is only thanks to the tenacity of the local NGOs that Vale has been prosecuted, three years after the accident. Ensemble pour la Planète is now waiting for Vale to be judged under civil law for prejudice to the fauna and flora.

According to Conservation International, New Caledonia is a 'biodiversity hotspot,' meaning it contains one of the richest and yet most threatened reservoirs of plants and animal life on earth. Cornailles can't believe Vale is allowed to mine in an area that has such a high rate of localised biodiversity. Ensemble pour la Planète has brought Vale to court at least 10 times, but has only won once. 'It's like banging our head against a brick wall, given the colossal human and financial means of Vale compared to those of the small group of volunteers that make up Ensemble pour la Planète,' says Cornailles.

On the day of the 2009 acid spill into the river, a faulty joint ruptured during testing at the acid plant. A high-pressure spray of 98 percent sulphuric acid shot out beyond the safety wall of the basin designed to contain spills. By the time the leak was stopped, 40,000 litres of acid had escaped, and 2500 litres reached the river.

New Caledonia's government sponsored the Lloyd's Register, a global risk management and safety assurance organisation, to lead an inquiry into the accident. Lloyd's found that the accident had been caused by a failure to identify or anticipate problems with the design of the joints, a failure to identify a shortfall in the existing operational set-up of the containment systems for on-site leaks, and that the consequences of the accident were made worse by the fact that staff had failed to appreciate the level of the security alert.

It noted that the on-site emergency response manager position had not been filled at the time of the testing, and the person standing in was off-site due to illness.

Lloyd's also found that the mining company did not make 'effective 


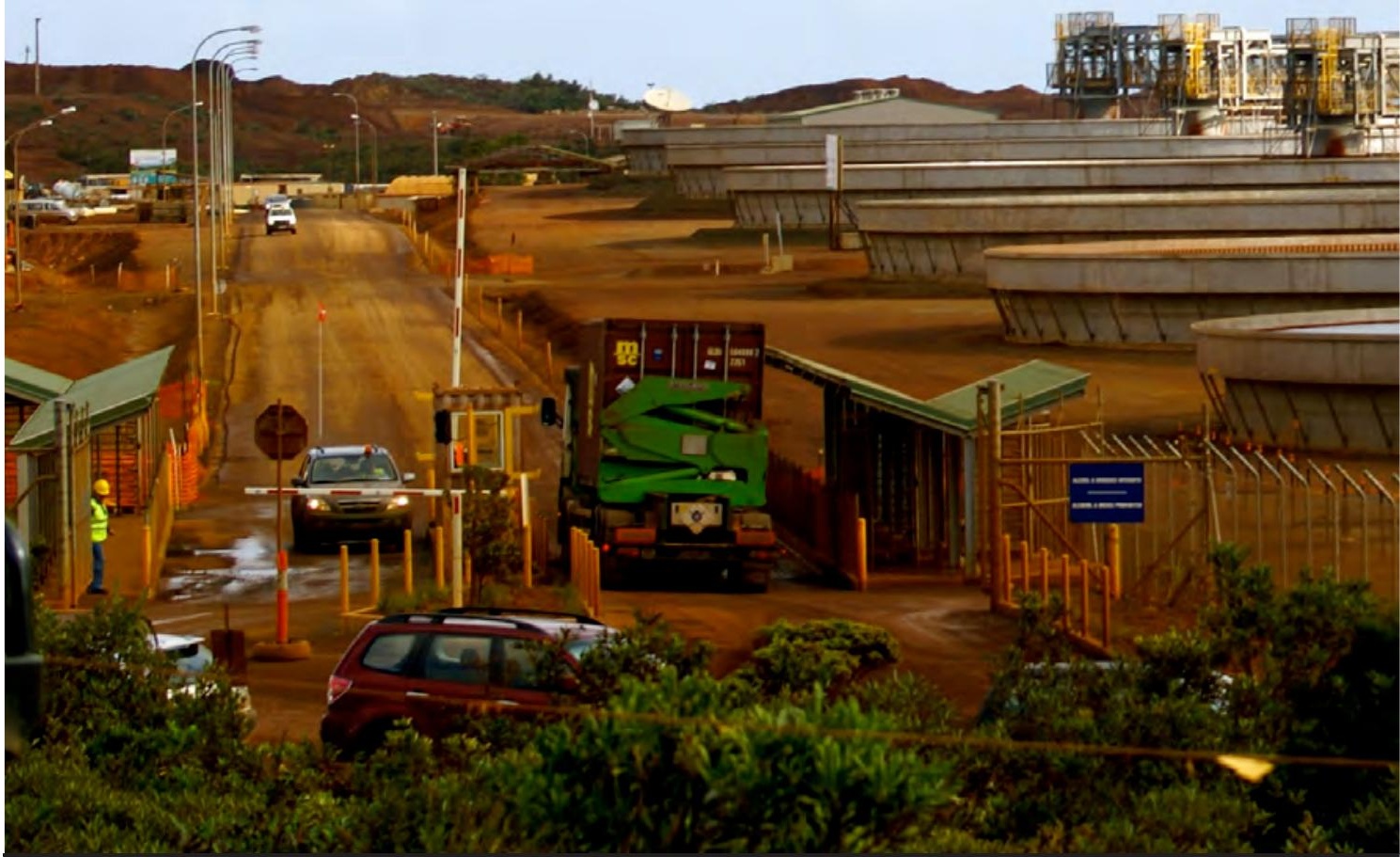

Figure 2: The Vale New Caledonia nickel refinery at Goro, New Caledonia.

contact' with New Caledonia's authorities or the public until the day after the accident. This, reported Lloyd's, 'resulted in community outrage evidenced by media reports, picketing the site and a day of mourning'.

Vale conducted its own internal investigation of the accident, after which it announced it would implement 84 concrete actions aimed at 'improving its plans to prevent and contain any industrial risk associated with its operations'. Vale would not be interviewed for this article, but agreed to answer some questions by email. Yet when asked how many safety actions have since been implemented, Vale did not reply by the time of publication.

In an email, Vale however wrote that it has invested 21 percent of its 


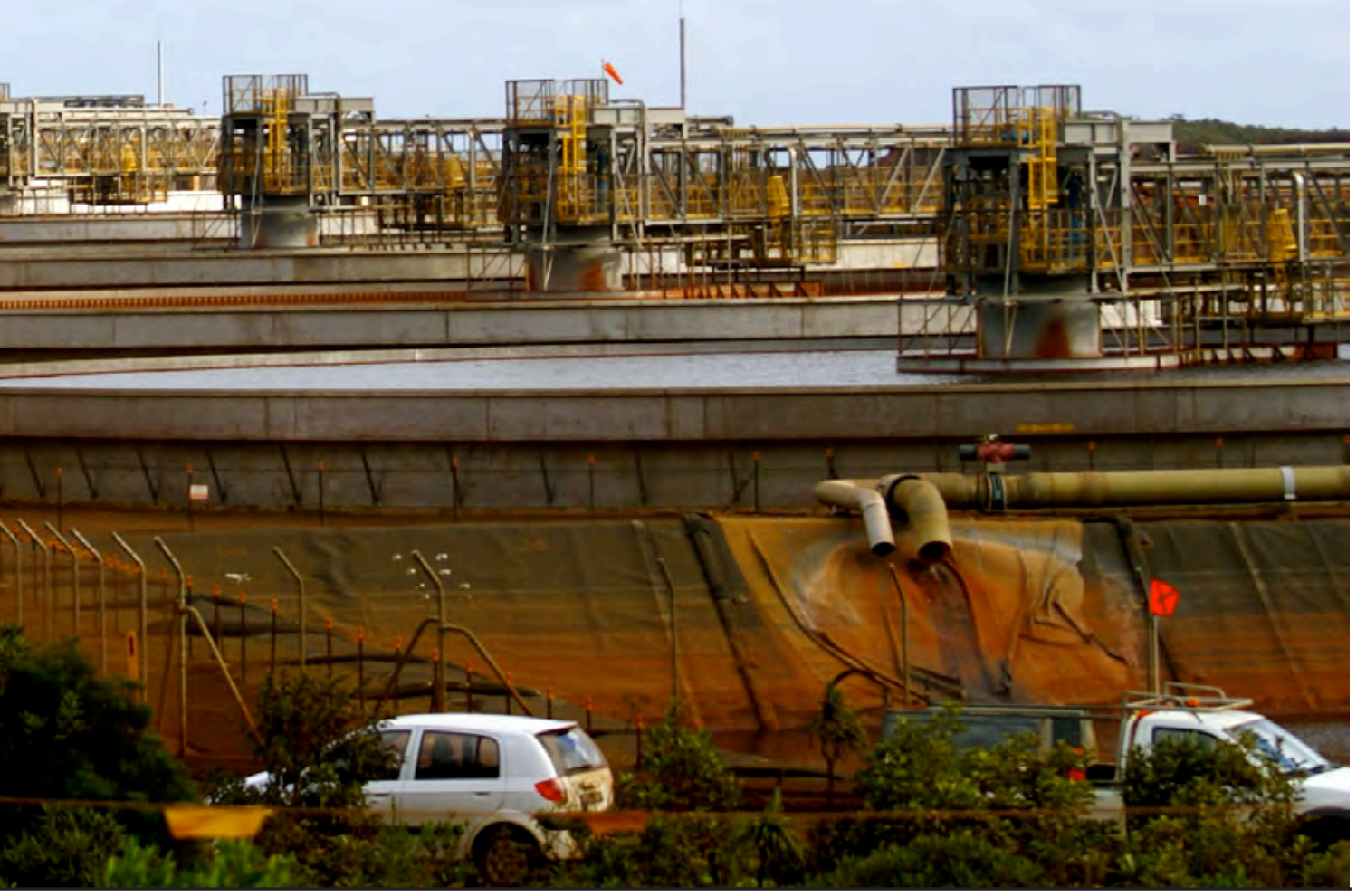

(c) NICOLE GOOCH 2010

total budget, about US\$900 million, into the protection of the environment. However, on the mountains of the lush and isolated island of Ile Ouen, directly across a narrow sea straight from the mine, people of the tribe of Ouara are still worried.

Fishing is a vital food source and locals are unimpressed with plans to release liquid metal waste from the nickel refining process into the sea.

In April 2008, before the signature of the 'Sustainable Development Agreement', the villagers joined forces with Ensemble pour la Planète and prominent indigenous environmental NGO, Rhéébù Nùù, to erect a Bois Tabou, Pii Kon Dââ Boâ, on a reef between the island and the mine. A Bois 
Tabou is a traditional grand wooden totem that calls for negotiations at times of threat, and defines an off-limits area.

Clan chief Olivier Wethy says his people are not necessarily against the mine-in fact many of the lle Ouen youth work at the mine and the tribe has created a successful transport business that subcontracts to Vale, but they are opposed to dumping waste in the sea.

The liquid residue is to be spewed out at a rate of up to 3000 cubic metres an hour into the lagoon bordering the UNESCO World Heritage site. It will contain dissolved metals, including manganese, as well as calcium, chloride and sodium sulphate. 'At twenty meters from the diffuser, it will be impossible to detect any difference between the discharged effluent and the lagoon water. There are no dangers for the coral reefs,' says Vale New Caledonia on its website.

But Chief Wethy says the government and Vale 'completely ignored our rights as indigenous people to take part in decisions about our environment, and to live up to our responsibilities towards future generations with regards to the protection of our environment'.

'As Kanaks, we believe the sea is inhabited by the spirit of our ancestors and we are responsible for it. As citizens and fishermen, who have been living off sea produce for thousands of years, we are worried that our food resources are endangered by the mine.'

Night comes fast upon the tribe of Ouara, on Île Ouen. A chilly wind from the ocean drifts through the village's green alleyways, sea air blending with wood-fire smoke still lingering after the day's work on the land. Lights bob up and down through the trees as families settle down to watch satellite TV, powered on sunny days by a combination of recycled oil shipped from MacDonald's in Nouméa and solar panels.

Many in the tribe of Ouara are descendants of the Kanaks who fled the mainland in the late 1870s, as Chief Atai led an insurrection against French Admiral Olry and colonial domination. Chief Atai's head has long since been removed from display in the anthropological museums of Paris, but the statue of Admiral Olry still dominates the main square of Nouméa's city centre.

Children from Île Ouen are sent to a public boarding school on the mainland these days, then, if possible, onto France for university studies. Once a month a government medical team rides the rough seas of the straight to tend to the sick in the tribe. Vale New Caledonia's community relations' programme is funding the restoration of the roof of the heritage listed village church, which blew away in a cyclone in 2003, and mini-NGOs have been set up to obtain local government funding for development activities. 
Chief Wethy and another of the village leaders, Chief Pascal Wadecla, hope to turn lle Ouen into a tourist destination, which would include a guided tour up a steep mountain from where, on a clear winter day, pods of endangered humpback whales can be seen performing a hardcore ballet of fierce tail slamming and breaching, as the males compete for attention on what is their main breeding ground in New Caledonia.

Kanak elders of past generations used to survey the lagoon from the top of this mountain, and it is where chiefs Olivier Wethy and Pascal Wadecla are now planning to erect the Bois Tabou, having had to remove it from the reef where it was in danger of sinking in the midst of rising tides.

Vale owns 74 percent of the Goro mine, while New Caledonia's three local provincial governments own 5 percent, with an obligation to go up to 10 percent, and the remainder is controlled by the Japanese consortium Sumitomo Mitsui SUMIC. It was originally owned by Canadian mining company Inco, until Vale, known at the time as CVRD, took over Inco in late 2006.

During the construction of the refinery, at the height of activity, 8000 people worked at the site. Much of the design and planning was undertaken in Australia, as well as in Canada and Thailand. In total, more than 15,000 people throughout the world were involved in the project, says Vale. It now employs 4000 staff, 1000 of which are directly employed, and the remainder are sub-contracted businesses, either local, Australian, Canadian or Filipino. Once the mine starts full production, the number of staff on site will be downscaled to about 1000 people.

Although Vale New Caledonia has not answered questions put to it directly by me on the topic, the company will benefit from a saving of US $\$ 100$ million, thanks to a tax incentive scheme for French investors worth about US $\$ 481$ million, facilitated by the French government. The French Senate report says this arrangement is 'unrivalled' and Vale is set to make further savings under a local New Caledonian law that grants mining companies 15 years of production tax free, followed by 50 percent tax-free for the next five years.

For New Caledonia's countryside is littered with small mines, while Nouméa hosts what has been until now the country's only nickel treatment plant, a traditional smelter operated with a petrol-fuelled power station. A similar smelter is currently being built in the north of New Caledonia, powered by coal. Once all three nickel refineries begin operating at the same time, the island stands to become one of the biggest $\mathrm{CO} 2$ polluters per capita in the world. 
A first Bois Tabou had already been erected in July 2002 near the mine, with the support of Rhéébù Nùù, lead by Raphael Mapou, now chief of staff of New Caledonia's Customary Senate. In 1992, Mapou had been mayor of Yaté, a neighbouring village of Goro, when Canadian mining company Inco first acquired the rights to the Goro nickel deposit, 'for next to nothing', according to Mapou.

And then, in 2002, 'the mine suddenly sprang out of nowhere, and Inco began cutting down hectares of forest, even though the mine didn't have an operating permit yet, or an approved environmental impact assessment'.

Rhéébù Nùù leaders tried to negotiate, but Mapou says they were frustrated by a 'complete lack of transparency'. Frustration compounded by the fact that Inco 'refused to deal directly with New Caledonia's indigenous people, the Kanaks, on the ground that France had not, at the time, signed the UN Declaration on Indigenous Rights'.

Meanwhile, intra-community turmoil increased over the legitimacy of the mine, and over the use of violence to respond to it. Many feared a return to the widespread violence known as Les Événements that marred New Caledonia during the pro-independence struggle against France in the 1980s.

In 2004, the Southern provincial government of New Caledonia awarded Inco its first operating permit, but Mapou says the environmental impact assessment was 'completely flimsy'. Rhéébù Nùù's opposition to the mine increased dramatically and, in April 2006, the NGO set up its biggest blockade, supported by villagers from the south of New Caledonia. Mapou and his colleagues held the fort under blue tarpaulins for more than a month, during which violent clashes with French troops took place. As trucks were engulfed in flames, black smoke rose from the deep red of the south, and the usual silence of the lunar landscape was interrupted for days on end by helicopters and the firing of tear gas.

According to media reports, Inco claimed the protesters caused US\$10 million worth of damage to equipment on the mine, and the police made more than 30 arrests, including Mapou a short while later.

Rhéébù Nùù was vindicated in June 2006 when the Administrative Tribunal of Nouméa cancelled the mine's operating permit. In his closing remarks, the government Commissioner, Jean-Paul Briseul, reminded the court of what he considered to be 'at the heart of the problem':

'How to reconcile this industrial project, at the forefront of technology with one of the world's most sensitive environments of the planet? That is the question'.

Briseul referred to the information report produced by the French Senate in 2005 , which highlighted that 'the success of the project depends on the 
total control of environmental aspects so as not to disfigure and damage irreversibly one of the most beautiful lagoons in the world onto which gives the Goro site'.

The public consultation on the project was marred by irregularities, and the impact assessment study was incomplete, said Briseul. He noted that INERIS, the French expert body commissioned to undertake one of the first impact studies, had concluded that it could not, given the current state of technical and scientific knowledge, determine exactly what impact the manganese would have on the marine environment.

Vale New Caledonia makes no mention of the tribunal's decision to revoke the mine's first permit on its website's historical timeline. It simply mentions that it requested a second operating permit in 2006, which was granted at the end of 2008. Construction on the mine never ceased.

It was mid- February 2008, when a flotilla of tugboats left the safety of the port of Nouméa to make its way south down the coast of New Caledonia. The convoy was 600 metres long, and at its centre was the infamous pipeline. The work on the installation of the pipeline was to go ahead, even though Vale still hadn't got a new operating permit for the mine.

But on its arrival in the south, Rhéébù Nùù, Ensemble pour la Planète and other NGOs greeted the pipeline with a wave of fury, supported this time by professional fishermen. Work on the pipeline was brought to a stop, but the protests continued over the next three months, with rallies in Nouméa and on boats in the south. They culminated in April 2008, when more than 300 people squeezed into little boats and headed to lle Ouen, where, after the usual custom ceremonies with the local villagers, they witnessed the erection of Pii Kon Dââ Boâ, the traditional Bois Tabou, on the reef off the island.

Given Mapou's long-time stance against the mine, it came as a surprise to many when he and other customary leaders agreed to the signature of the Sustainable Development Agreement with Vale in September 2008. Under the terms of the agreement, Vale is to fund reforestation of over 2000 ha of land, as well as l'Oeil - 'the Eye' in French, a new environmental monitoring body for the south. Mapou is president of l'Oeil until June this year, while Cornailles, from Ensemble pour la Planète, is second vice-president.

'I know that for many people, it felt as if we were simply giving up, especially for young Kanaks in their twenties, for whom this fight was the equivalent of the one we fought in the 80 s against France,' says Mapou.

'But I warned them: if you want to keep on fighting to win, people will have to die. And we fought in the 1980s for independence, but here we are 
nearly 30 years later and we are still in a process of decolonisation towards independence-if we ever get there.'

Mapou says it was a matter of 'being realistic', and of 'trying to stay true to oneself while being able to turn the mine into something positive'.

'Signing the agreement was not an easy decision,' says Mapou. 'We didn't want this refinery, but we had also become very divided because the mine had lured people to it with lucrative promises of work and it was causing a lot of friction within villages.'

'We felt isolated,' says Mapou, 'so we designed a strategy to oblige the mining company and the Southern provincial government to negotiate with us, to agree on an appropriate way out that would allow us to frame our fight as indigenous people for the decades to come'.

But Chief Wadecla, from lle Ouen, says he does not trust the environmental body, l'Oeil, to be sufficiently independent. 'Vale, Rhéébù Nùù and the Southern provincial government are all playing a game together,' he says. 'The words of the agreement have been trampled on.'

Wadecla is not alone in harbouring such feelings. The walls of the town hall of Yaté, where Mapou is from, were vandalised after the signature of the agreement and covered in accusations of corruption. But Mapou says he has 'never received a cent from either Inco or Vale'.

'When Vale took over Inco and was trying to find its feet in New Caledonia, the company owners played the game and the final content of the agreement was drafted on the basis of what we wanted, even if we didn't get everything.

'So why would I have asked for money in exchange for an agreement that Rhéébù Nùù had dictated, and what sort of industrial company would pay us to impose on it an agreement, of which it had no need given the balance of power?' argues Mapou.

Meanwhile, Philippe Gomez, who awarded Inco its first operating permit in 2004 as President of the Southern provincial government, and later went on to become President of New Caledonia's territorial government, was ordered to appear in front of Nouméa's tribunal at the end of March this year. Gomez was a majority stakeholder in a company called Spot when, according to local media, it sold to Inco, between March 2005 and February 2006, 1200 air-conditioning units worth about AU\$1 million. The judges' decision on the matter was not known at the time of publication.

Mapou's main concern today is that Vale has agreed to abide by prescribed emission thresholds, but, given that chemical mining is a new field of knowledge, he fears 'we will only know of the mine's true environmental 
impact once the refinery is totally operational, and provided the monitoring and evaluation systems are well designed'.

L'Oeil is building a new set of environmental indicators, but Mapou is worried it will not be ready until 2014-2015. 'In the meanwhile, we have noticed, and reported, problems such as gas leaks over trees near the refinery, and problems with the treatment of waste water that is discharged into rivers,' says Mapou.

Sylvain Meallet, leader of the workers' union Force Ouvrière, shares similar concerns to Mapou regarding the lack of efficient monitoring systems. While Meallet acknowledges Vale's efforts to apply Sevoso II safety standards to the mine, he says New Caledonia does not have the same sophisticated systems and capacity for monitoring as Europe has.

'The government promised in 2009 to bring a Sevoso inspector from France to check installations and safety regulations, but that never happened,' said Meallet in July 2010. 'Nothing has changed.'

When I contacted Vale, the company did not respond to questions concerning the visit of a Sevoso inspector.

Martine Cornailles, president of Ensemble pour la Planète, is less measured than Meallet. She says the level of risk posed by high-pressure acid leaching is simply not acceptable. 'It is all well and good to have grand safety plans, but the reality is that, in the event of an explosion, chances of survival are limited,' says Cornailles. 'They just have no right to do that to people.'

In a July 2010 interview, Meallet also argued that the risk of an explosion or environmental pollution happening was made greater by what he described as 'gross negligence and amateurism' in terms of management of the plant.

In September 2009, six months after the accident of the acid spill in the river, representatives of the union Force Ouvrière met leaders of the government with a list of grievances and incidents that highlighted mismanagement at the Vale New Caledonia plant. Employees had complained that many units of the refinery were under-staffed and the remaining workers lacked training and experience, yet were still made to work over-time, sometimes 24 hours non-stop, in a dangerous environment.

The unionists' report handed over to the government also included statements by witnesses shocked by the lack of 'fundamental knowledge' of management in chemical engineering, or incredulous at the fact that safety gear was not available when needed as it was locked in a container.

Meallet believed Vale was cutting corners in its rush to start production, initially planned for 2008. And, combined with low morale and fatigue among staff, it had created a recipe for disaster. 
'Some of the incidents highlighted in our report could be considered normal for such a complex installation,' said Meallet at the time. 'Except that in the Vale New Caledonia case, there was no staff available or trained to deal with these incidents, and it is well-known that it is a string of such incidents that often leads to catastrophes.' Vale has not replied to questions about the report.

Meallet now says he doesn't know if much has changed over the last couple of years as the workers who had made the complaints have all since left, 'but at least there have been no more accidents.' He says he is not against the mine, but wants to 'insure the safety of workers and the economical soundness' of the project.

Back at the village of Goro, where the river once run green, the village is quiet again, and the wind that used to bring Kanaks from the outer-islands to this little bit of the mainland, in their outriggers, today nurtures nothing but a stream of grey clouds.

Surrounded by a garden of delicate flowers, diminutive Maeva Dremon is making necklaces for her grandchildren, while next to her lies a heavy stack of papers documenting her dealings with Vale New Caledonia.

She may be small, but Dremon is not faint hearted. Her grandfather, a priest, was one of the Kanaks exchanged against crocodiles for a zoo in Frankfurt during the 1931 Colonial Exhibition in Paris. Then, at the height of the protests against the mine in 2006, she stormed her clan's barricades, fed up that her grandchildren were missing classes because the school bus could not get through.

Yet Dremon says she feels tiny compared to the big multinationalsVale and BHP Billiton are just two among many mining companies to have expressed interest in acquiring mining rights to another low-grade ore nickel deposit near Goro.

'In 50 years time, or 100 years time, what will happen? What will be left for our great-grandchildren of the environment and of our culture?' asks Dremon.

In the meantime, Martine Cornailles, from Ensemble pour la Planète, has written to the UN's Office of the High Commissioner for Human Rights, asking it to send its experts to report on health risks and environmental destruction caused by Vale and other mining operations in New Caledonia. Ensemble pour la Planète has also recently mounted three more civil procedures, including one against a new authorisation that allows Vale to clear more land officially classified as an 'ecosystem asset'. 